\title{
ANALISIS EFEKTIVITAS MESIN PRESSING PH-1400 DENGAN METODE OVERALL EQUIPMENT EFFECTIVENESS (OEE) DI PT. SURYA SIAM KERAMIK
}

\author{
Lingga Tiyas Atmaja ${ }^{1)}$, Edi Supriyadi' ${ }^{2}$, Sri Utaminingsih ${ }^{2}$ \\ ${ }^{1)}$ Mahasiswi Program Studi Teknik Industri Universitas Pamulang \\ ${ }^{2}$ Dosen Fakultas Teknik Program Studi Teknik Industri Universitas Pamulang \\ dosen00456@unpam.ac.id
}

\begin{abstract}
ABSTRAK
PT. Surya Siam Keramik adalah sebuah perusahaan swasta yang bergerak dibidang keramik lantai dan keramik dinding. Pada penelitian ini penulis membahas tentang mesin yang memproduksi keramik lantai yaitu mesin pressing PH-1400. Penulis menganalisa efektifitas mesin pressing yang digunakan untuk memproduksi dalam periode Januari 2016 sampai dengan Desember 2016. Metode yang digunakan oleh penulis adalah Overall Equipment Effectiveness (OEE). Dari hasil analisa selama periode Januari 2016 sampai dengan Desember 2016 nilai OEE berkisar antara 71.55\%-92.00\% dengan rata-rata nilai $83.56 \%$. Hasil perhitungan nilai availability rate berkisar antara $84.32 \%$ 93.00\% dengan rata-rata nilai $89.28 \%$, nilai perfomance rate berkisar antara $77.18 \%-99.73 \%$ dengan rata-rata nilai $94.01 \%$, dan nilai quality rate berkisar antara $99.53 \%-99.73 \%$ dengan rata-rata nilai 99.65\%. Nilai OEE masih berada dibawah standar kelas OEE yaitu $85 \%$. Penulis memberikan usulan perbaikan melalui perawatan pada mesin yang baik seperti inspeksi dan preventive maintenance secara berkala atau dengan cara mengganti mesin pressing dengan yang baru. Hasil perhitungan biaya perawatan lebih murah yaitu sebesar IDR 2,142,866,208.46,- dibandingkan dengan biaya pembelian mesin baru sebesar IDR 5,476,266,340.08,--
\end{abstract}

Kata kunci: Proses Produksi, Overall Equipment Effectiveness, Biaya Perawatan.

\section{A. PENDAHULUAN}

Produksi keramik lantai menggunakan beberapa unit mesin-mesin besar, seperti Crushing Machine, Ball Mill, Spray Dryer, Pressing, Vertical Drier, Glazing dan Kiln. Dari tahapan-tahapan mesin tersebut, produktivitas diukur setelah melalui mesin Pressing karena mesin Pressing menghasilkan tile/ubin dengan satuan meter persegi/sqm yang merupakan satuan pengukuran produktivitas pada bagian produksi. Proses produksi pada line 104 merupakan line penghasil keramik lantai berukuran $40 \times 40 \mathrm{~cm}$ mengalami permasalahan penurunan produktivitas yang diakibatkan oleh tingginya intensitas mesin stop. Hal ini tentunya menimbulkan kerugian bagi perusahaan dari segi waktu, biaya yang dikeluarkan untuk perbaikan, biaya produksi yang meningkat, maupun pada peluang tercapainya target harian yang semakin kecil. Oleh karena itu, diperlukan suatu tindakan untuk dapat meminimasi masalah yang timbul dan meningkatkan produktivitas secara signifikan. Salah satu pendekatan yang digunakan untuk menanggulangi permasalahan ini adalah dengan metode Overall Equipment Effectiveness atau disingkat dengan OEE). Pengukuran kinerja dengan OEE (Overall Equipment Effectiveness) terdiri dari 3 komponen utama pada mesin produksi yaitu Availability (waktu kesediaan mesin), Performance (jumlah unit yang diproduksi) dan Quality (mutu yang dihasilkan).

\section{LANDASAN TEORI}

\section{A. Produktivitas}

Produktivitas merupakan istilah dalam kegiatan produksi sebagai perbandingan antara luaran (output) dengan masukan (input). Produktivitas merupakan suatu ukuran yang menyatakan bagaimana baiknya sumber daya diatur dan dimanfaatkan untuk mencapai hasil yang optimal (Herjanto: 2007). Perawatan adalah aktivitas pemeliharaan, perbaikan, penggantian, pembersihan, penyetelan, dan pemeriksaan terhadap objek yang dirawat. 
Manajemen perawatan industri adalah upaya pengaturan aktivitas untuk menjaga kontinuitas produksi, sehingga dapat menghasilkan produk

\section{B. Overall Equipment Effectiveness (OEE)}

\section{OEE (Overall Equipment} Effectiveness) adalah standar emas untuk mengukur produktivitas manufaktur. Sederhananya, OEE dapat mengidentifikasi persentase waktu manufaktur yang benar-benar produktif. Suatu produksi dikatakan sempurna apabila nilai OEEnya mencapai $100 \%$. Hal ini menandakan bahwa produksi tersebut telah melengkapi beberapa unsur seperti: $100 \%$ quality (only good parts), $100 \%$ performance (performansi), dan $100 \%$ availability (ketersediaan) tanpa adanya waktu stop.

\section{Diagram Pareto dan Fishbone}

Diagram ini diperkenalkan pertama kali oleh seorang ahli ekonomi dari Italia bernama Vilfredo Pareto (1848-1923). Diagram pareto dibuat untuk menemukan masalah atau penyebab yang merupakan kunci dalam penyelesaian masalah dan perbandingan terhadap keseluruhan. Dengan mengetahui penyebab-penyebab yang dominan (yang seharusnya pertama kali diatasi) maka kita akan bisa menetapkan prioritas perbaikan. Fishbone diagram (diagram tulang ikan-karena bentuknya seperti tulang ikan) sering juga disebut Cause-and-Effect Diagram. Fishbone diagram digunakan ketika kita ingin mengidentifikasi kemungkinan penyebab masalah dan terutama ketika sebuah team cenderung jatuh berpikir pada rutinitas (Tague, 2005).

\section{Nominal Group Technic (NGT)}

Nominal Grup Technique merupakan suatu metode terstruktur yang digunakan untuk

\section{HASIL DAN PEMBAHASAN}

\section{A. Pengumpulan Data}

Data hasil produksi Mesin Pressing PH-1400 dari bulan Januari 2016 sampai yang berkualitas dan memiliki daya saing, melalui pemeliharaan fasilitas industri (Kurniawan, 2013).

menggali lebih dalam kontribusi setiap peserta NGT. The nominal group technique (NGT) is a group problem solving process involving problem identification, solution generation, and decision making (Delbecq dan VandeVen, 1971).

\section{E. Analisa 5W+1H}

$5 \mathrm{~W} 1 \mathrm{H}$ merupakan singkatan dari $5 \mathrm{~W}$ yaitu What, Where, When, Why, Who dan $1 \mathrm{H}$ yaitu How. 5W1H pada dasarnya adalah suatu metode yang digunakan untuk melakukan investigasi dan penelitian terhadap masalah yang terjadi dalam proses produksi. Konsep ataupun Metode 5W1H ini tentunya tidak hanya dapat digunakan dalam proses produksi.

\section{METODOLOGI PENELITIAN}

Penelitian ini akan dilakukan di PT. Surya Siam Keramik, Serpong-Tangerang Selatan. Dan pengambilan data dilakukan untuk menghitung nilai OEE mesin Pressing $\mathrm{PH}-$ 1400. Penelitian dilakukan selama 6 bulan, dimulai dari bulan Januari 2017 sampai dengan Juni 2017.

Penelitian ini menggunakan tipe penelitian deskriptif dengan pendekatan kuantitatif. Penelitian deskriptif dalam penelitian ini dimaksudkan untuk mendapatkan gambaran dan keterangan-keterangan mengenai kemampuan mesin Pressing PH1400 dan untuk mencapai tujuan dari penelitian ini, maka penulis menggunakan metode Overall Equipment Effectiveness (OEE).

dengan Desember 2016 yang diperoleh penulis dan akan diolah pada penelitian ini dapat dilihat pada Tabel 4.1: 


\begin{tabular}{|c|c|c|c|c|}
\hline Tahiun & Bulnm & $\begin{array}{l}\text { Impue } \\
\text { (Sigm) }\end{array}$ & $\begin{array}{l}\text { Waste } \\
\text { (Sigm) }\end{array}$ & $\begin{array}{l}\text { Output } \\
\text { (sqm) }\end{array}$ \\
\hline \multirow{12}{*}{2016} & Jaxiagi & 83,173 & 252 & 82,921 \\
\hline & Pebruari & 70,974 & 328 & 76,646 \\
\hline & Maret & 85,759 & 228 & 85,530 \\
\hline & April & 76.292 & 259 & 76,033 \\
\hline & Mei & 83,957 & 236 & 83,722 \\
\hline & Jumi & 82,151 & 271 & 81,879 \\
\hline & Juki & 75,466 & 236 & 75,231 \\
\hline & Agrustus & 80,535 & 286 & 80,249 \\
\hline & Soptember & 80,118 & 278 & 79,841 \\
\hline & Okctabex & 77,694 & 286 & 77,408 \\
\hline & Nopemiber & 80,721 & 355 & 80,365 \\
\hline & Desember & 79,341 & 372 & 78,969 \\
\hline \multicolumn{4}{|c|}{ Rata-Rata } & 79,899 \\
\hline
\end{tabular}

Dari data diatas diperoleh rata-rata Output Mesin Pressing sebesar 79,899 Sqm. Output tertinggi diperoleh pada bulan Maret 2016 sebesar 85,530 Sqm, dan Output terendah diperoleh pada bulan Juli 2016 yaitu sebesar 75,231 Sqm. Data-data yang terkait dengan Downtime Mesin Pressing PH-1400 Line 104 dapat dilihat pada Tabel 4.2:

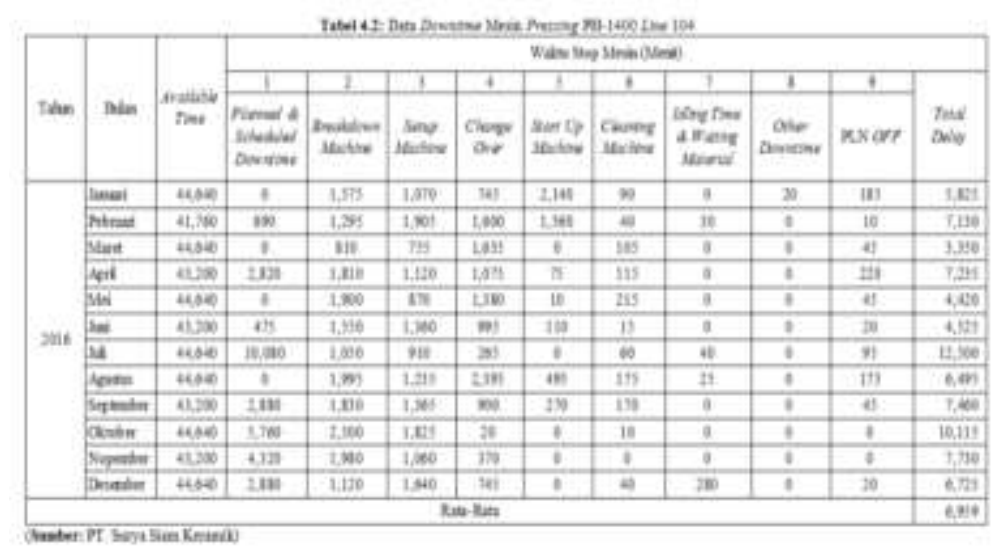

Dari data Downtime diatas diperoleh nilai rata-rata total delay mesin adalah sebesar 6,959 menit. Total jam henti mesin terbesar terjadi pada bulan Juli 2016 yaitu sebesar

\section{B. Perhitungan Loading Time}

Hasil perhitungan Loading Time pada penelitian ini dapat dilihat pada Tabel 4.3 dengan rumus perhitungan sebagai berikut:

Loading Time - Available Time - Planned Downtime Laading Time $=44,640-0=44,640$

Dari perhitungan Loading Time diatas diperoleh nilai rata-rata sebesar 41,428 menit. Loading time terbesar diperoleh pada bulan Januari, Maret, Mei dan Agustus 2016 yaitu sebesar 44,640 menit dengan 0 menit Planned \& Scheduled Downtime pada bulan-bulan
12,500 menit, dan total jam henti mesin terkecil diperoleh pada bulan Maret 2016 yaitu sebesar 3,350 menit.

tersebut. Loading Time terkecil diperoleh pada bulan Juli 2016 yaitu sebesar 34,560 menit.

\section{Perhitungan Availability Rate}

Hasil perhitungan dari Availability Rate merupakan persentase. Persentase hasil perhitungan Availability Rate dibulatkan pada 2 (dua) angka di belakang koma.

$$
\begin{gathered}
\text { Availability }=\frac{\text { Operating Time }}{\text { Loading Tims }}=\frac{\text { Loading Time }- \text { Downzime }}{\text { Loading Time }} \times 100 \% \\
\text { Aveullability }=\frac{(44,640-5,825)}{44,640} \times 100 \%-86.95 \%
\end{gathered}
$$

Dari perhitungan diatas diperoleh nilai rata-rata Availability Rate adalah sebesar 
89.28\%. Availability Rate terbesar diperoleh pada bulan Juli 2016 yaitu sebesar $93.00 \%$, dan Availability Rate mesin terendah diperoleh pada bulan Pebruari 2016 yaitu sebesar 84.32\%.

\section{Perhitungan Performance Rate}

Hasil perhitungan persentase jam kerja mesin efektif dibulatkan pada 2 (dua) angka dibelakang koma

$$
\begin{aligned}
& \text { Persentase Jain Kerja }=1-\left(\frac{\text { Total Delay }}{\text { Awailable Trmos }}\right) \times 100 \% \\
& \text { Persentase Jam Kerja }=1-\left(\frac{5,825}{44.640}\right) \times 100 \%=86,95 \%
\end{aligned}
$$

Dari perhitungan diatas diperoleh nilai rata-rata jam kerja efektif mesin adalah sebesar $84.15 \%$. Jam kerja mesin tertinggi diperoleh pada bulan Maret 2016 yaitu sebesar 92.50\%, dan jam kerja mesin terendah diperoleh pada bulan Juli 2016 yaitu sebesar $72.00 \%$. Selanjutnya menghitung ideal cycle time atau waktu siklus ideal mesin beroperasi. Hasil perhitungan ideal cycle time dengan rumus perhitungan sebagai berikut ini:

Cycle Time $=\frac{\text { Loading Time }}{\text { Hasil Produksi }}$
Cycle Time $-\frac{44,640}{83,173}-0,5367$
Ideal Cycle Time - Cycie Time $x$ Prsentase Jam Kerja Nesin
Ideal Cycle Tome $=0,5367 \times 86.951 \%=0,4667$

Hasil perhitungan ideal cycle time dibulatkan 4 (empat) angka dibelakang koma. Nilai rata-rata perhitungan ideal cycle time adalah $0.4354 \mathrm{menit} / \mathrm{sqm}$ dengan nilai tertinggi diperoleh pada bulan Maret 2016 dengan $0.4815 \mathrm{menit} / \mathrm{sqm}$ dan nilai terendah diperoleh pada bulan Juli 2016 dengan 0.3297 menit/sqm. Selanjutnya menghitung Performance Rate. Hasil perhitungan performance rate dengan rumus perhitungan sebagai berikut:

\section{G. Analisa Diagram Pareto}

Setelah memperoleh data-data downtime pada Mesin Pressing PH-1400 Line 104, maka selanjutnya dapat dituangkan ke dalam diagram pareto dengan tujuan untuk

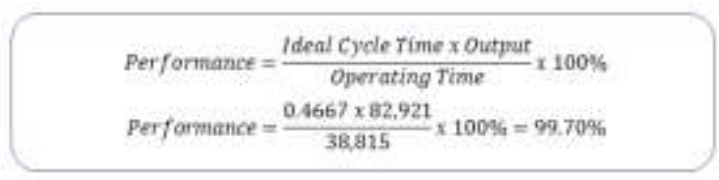

Dari perhitungan diatas diperoleh nilai rata-rata Performance Rate adalah sebesar $94.01 \%$. Performance rate tertinggi diperoleh pada bulan Maret 2016 yaitu sebesar 99.73\%, dan performance rate terendah diperoleh pada bulan Juli 2016 yaitu sebesar 77.18\%.

\section{E. Perhitungan Quality Rate}

Hasil perhitungan quality rate dengan rumus perhitungan sebagai berikut:

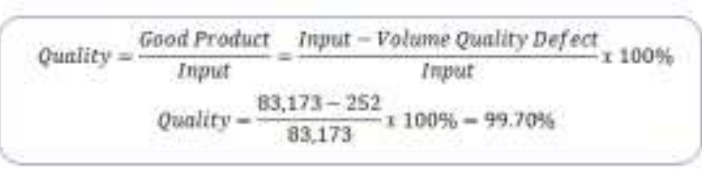

Dari perhitungan diatas diperoleh nilai rata-rata Quality Rate adalah sebesar 99.65\%. Quality rate tertinggi diperoleh pada bulan Maret 2016 yaitu sebesar $99.73 \%$, dan quality rate terendah diperoleh pada bulan Desember 2016 yaitu sebesar $99.53 \%$.

\section{F. Perhitungan Overall Equipment Effectiveness (OEE)}

Hasil perhitungan OEE dengan rumus perhitungan sebagai berikut:

OEE - Availability (\%) $\times$ Per formunce (\%) x Quaity (\%) $O E E-86.95 \% \times 99.70 \% \times 99,7030-86.43 \%$

Dari perhitungan diatas diperoleh nilai rata-rata OEE adalah sebesar $83.56 \%$. Nilai OEE tertinggi diperoleh pada bulan Maret 2016 yaitu sebesar $92.00 \%$, dan nilai OEE terendah diperoleh pada bulan Juli 2016 yaitu sebesar $71.55 \%$.

mempermudah analisa jenis downtime mesin yang paling dominan dan mempengaruhi efektivitas kerja mesin, diagram pareto dapat dilihat pada Gambar 4.18: 


\begin{tabular}{|c|c|c|c|c|c|c|c|c|c|}
\hline \multirow[b]{3}{*}{ Tatun } & \multirow[b]{3}{*}{ Dutan } & \multicolumn{8}{|c|}{ Wakns Stop Minin QMinno } \\
\hline & & 1 & 2 & 3 & 4 & 3 & 6 & 7 & 3 \\
\hline & & 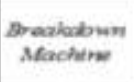 & $\begin{array}{c}\text { Setup } \\
\text { Machlober }\end{array}$ & $\begin{array}{l}\text { Chares } \\
\text { Over }\end{array}$ & $\begin{array}{l}\text { Start Up } \\
\text { Acohehere }\end{array}$ & $\begin{array}{l}\text { Cleanbe } \\
\text { Machina }\end{array}$ & 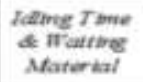 & $\begin{array}{c}\text { Other } \\
\text { Dontritowe }\end{array}$ & PLN OFF \\
\hline \multirow{12}{*}{2016} & Iarnanti & 1.575 & 1.070 & 745 & 2.140 & 90 & 0 & 20 & 185 \\
\hline & Pobruari & 1.205 & 1.905 & 1.600 & 1.560 & 40 & 30 & 0 & 10 \\
\hline & Maret & 810 & 755 & 1.635 & 0 & 105 & 0 & 0 & 45 \\
\hline & Apin & 1.810 & 1.120 & 1.075 & 75 & 115 & 0 & 0 & 220 \\
\hline & $\mathrm{Me}$ & 1,900 & 870 & $1,3 \mathrm{so}$ & 10 & 215 & 0 & 0 & 45 \\
\hline & Jun: & 1,550 & 1,360 & 995 & 110 & 15 & 0 & 0 & 20 \\
\hline & Fun & 1,050 & 910 & 265 & 0 & 60 & 40 & 0 & 93 \\
\hline & Agentus & 1,993 & 1.235 & 2,393 & 495 & 175 & 23 & 0 & 179 \\
\hline & Septanber & 1,830 & 1.365 & 900 & 270 & 170 & 0 & 0 & 45 \\
\hline & Olctober & 2,500 & 1,825 & 20 & 0 & 10 & 0 & 0 & 0 \\
\hline & Nopenber & 1,950 & 1,060 & 370 & 0 & 0 & 0 & 0 & 0 \\
\hline & Denember & 1,120 & 1.640 & 745 & 0 & 40 & 280 & 0 & 20 \\
\hline \multicolumn{2}{|c|}{ Jumlah } & 19,419 & 15,115 & 12,125 & 4.660 & 1.035 & 375 & 20 & 860 \\
\hline
\end{tabular}

(Sumber: Hasil Pengolahan Sendiri)

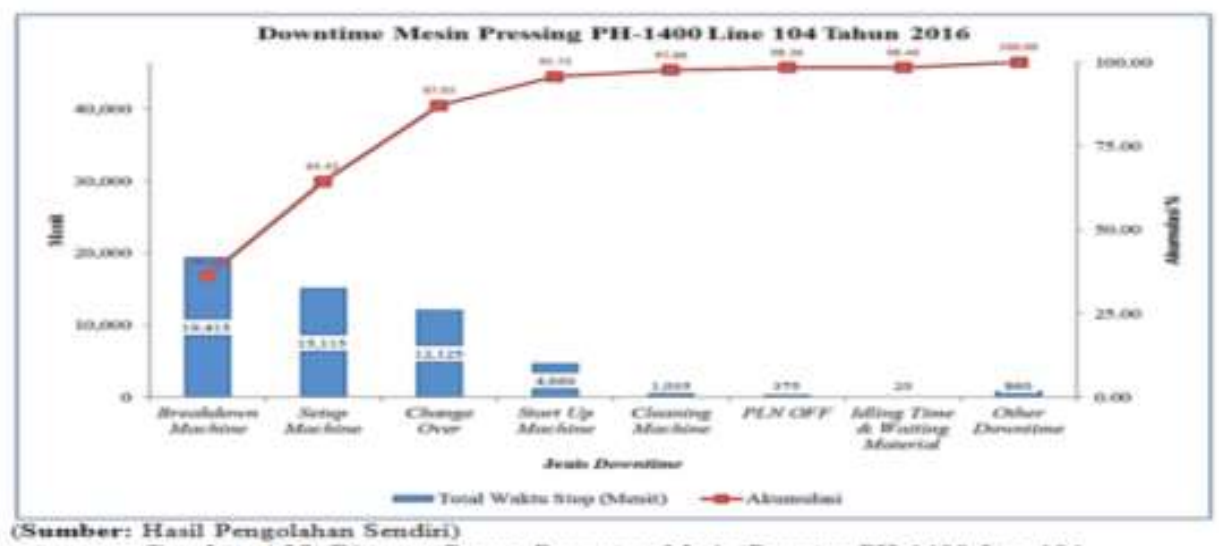

Gambar 4.181 Diagram Pareto Donvmine Mesin Presamg PH-1400 Zme 104

Dari analisa menggunakan diagram pareto ditemukan bahwa Breakdown Machine merupakan faktor terbesar yang mempengaruhi efektivitas Mesin Pressing PH-1400 Line 104 yaitu sebesar 19,415 menit yang selanjutnya adalah Setup Machine sebesar 15,115 menit dan Change Over sebesar 12,125 menit. Setelah ditemukan breakdown machine merupakan faktor terbesar yang mempengaruhi efektivitas Mesin Pressing PH-1400 Line 104, maka diperoleh 10 (sepuluh) jenis kasus breakdown machine tertinggi yang dapat dilihat pada Tabel 4.12:

Tabel 4.12: Jenis Kasus Breakdown Machine Pressing PH-1400 Tahun 2016

Tabel 4.12: Jenis Kasus Breakdown Machine Pressing PH-1400 Tahun 2016
\begin{tabular}{|l|c|l|c|}
\hline M es in & E/M & \multicolumn{1}{|c|}{ Hem } & $\begin{array}{c}\text { Waktu S top } \\
\text { (M enit) }\end{array}$ \\
\hline PH-104 & M & Pressure pressing abnomat (tidak stabid) & 7283 \\
\hline PH-104 & M & Balik /ganti frame ( karena kerusakan) & 1785 \\
\hline PH-104 & E & Alarm pressing & 1710 \\
\hline PH-104 & M & Ganti mo tor terbakar/o verload/dsb & 1100 \\
\hline PH-104 & M & Tambah oli & 930 \\
\hline PH-104 & M & Ganti selang & 920 \\
\hline PH-104 & M & Perbaikan motor & 890 \\
\hline PH-104 & E & Perbaikan panel torbakar/overload & 365 \\
\hline PH-104 & M & Gantio-ring & 355 \\
\hline PH-104 & M & Perbaikan selang bocor & 325 \\
\hline
\end{tabular}

(Sumber: Hasil Pengolahan Sendiri) 


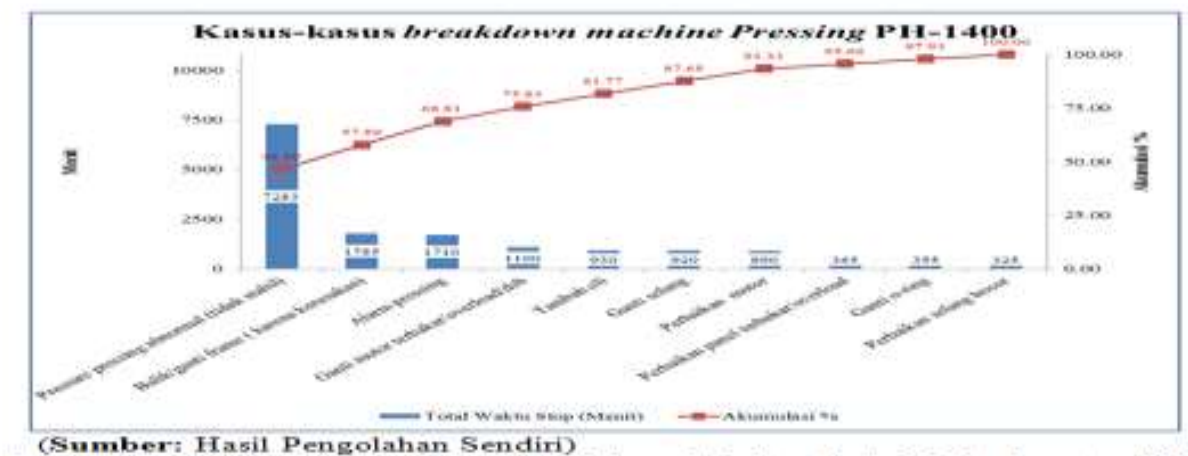

Gambar 4.19: Diagram Parero Kasus Breakdown Mcrehine Pada Mesin Pressing PH-140O

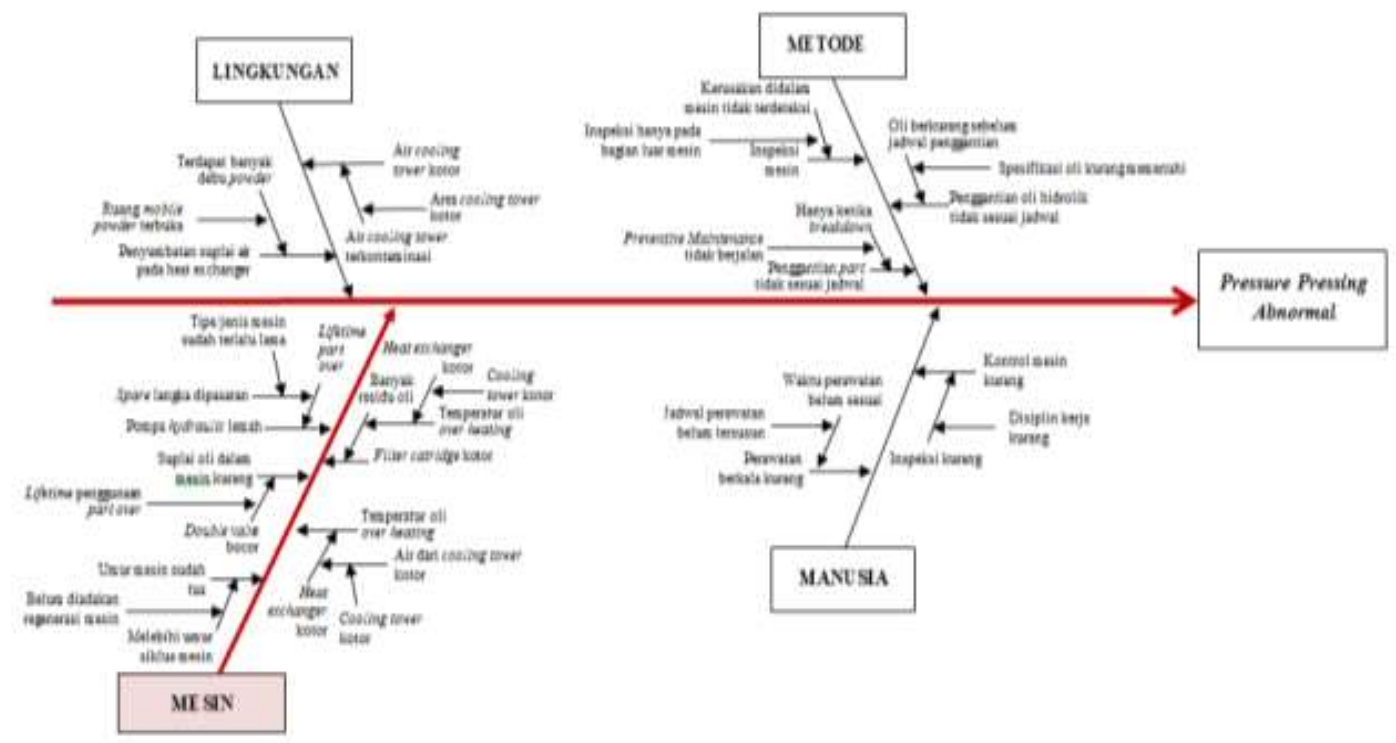

(Sumber: Hail Pengolahan Sendiri)

Gambar 4.20: Diagraw Fuhbene Kanus Awakdowh Machime Pada Mesin Presaing PH-1400

Dari diagram pareto diatas ditemukan bahwa kasus terbesar yang terjadi pada Mesin Pressing PH-1400 Line 104 adalah Pressure Pressing Abnormal (tidak stabil) yaitu sebesar 7,283 menit pada tahun 2016.

\section{H. Analisa Diagram Fishbone}

Analisa faktor-faktor penyebab terjadi pressure pressing abnormal adalah:

1. Faktor metode dimana inspeksi yang sudah dilakukan hanya pada bagian luar mesin dan sekitarnya, preventive maintenance yang tidak berjalan, dan spesifikasi oli hidrolik yang kurang memenuhi standar.

2. Faktor manusia dimana displin dalam melaksanakan inspeksi mesin kurang dan jadwal perawatan belum tersusun.

3. Faktor mesin dimana lifetime penggunaan part pada mesin yang sudah over, oli hidrolik yang cepat panas diakibatkan oleh
Hasil analisa dengan diagram fishbone digambarkan seperti pada Gambar 4.20 berikut ini

cooling tower yang kotor sehingga air yang disalurkan oleh cooling tower ikut kotor. Serta umur mesin Pressing PH-1400 yang digunakan sekarang ini sudah cukup tua ikut ambil andil dalam kasus ini.

4. Faktor lingkungan dimana kondisi disekitar mesin yang kotor dikarenakan ruang mobile/perpindahan powder terbuka sehingga powder berterbangan menyebabkan mesin-mesin disekitarnya menjadi cepat kotor dan air dari cooling tower yang kotor menyebabkan pengendapan pada heat exchanger sehingga 
5. bekerja menjadi tidak optimal.

\section{Analisa Nominal Group Technic (NGT)}

Hasil analisa menggunakan NGT dapat dilihat pada Tabel 4.13:

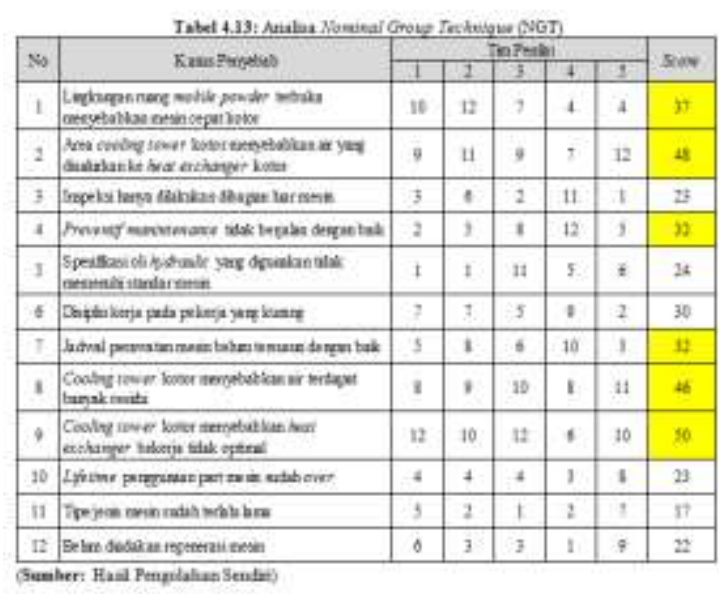

Rumus:

$$
\begin{aligned}
N G T & \geq \frac{1}{2} N+1 \\
N G T & \geq \frac{1}{2} 60+1 \\
N G T & \geq 30+1 \\
N G T & \geq 31
\end{aligned}
$$

Berdasarkan perhitungan diatas diperoleh nilai perbandingan NGT adalah sebesar 31 (tiga puluh satu) dan hasil analisa menunjukkan adanya 6 (enam) penyebab yang paling dominan dalam kasus pressure pressing abnormal (tidak stabil).

\section{J. Analisa 5W+1H}

Analisa $5 \mathrm{~W}+1 \mathrm{H}$ dapat dilihat pada

\section{Tabel 4.14:}

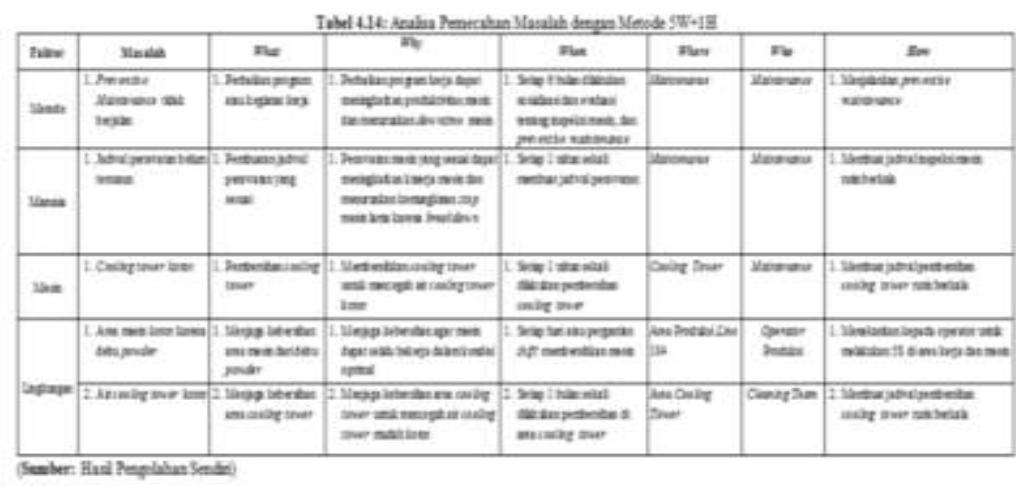

\section{K. Usulan Perbaikan}

Berikut ini merupakan analisa usulan perbaikan pada masalah breakdown machine

\begin{tabular}{|c|c|c|}
\hline Faktor & Penyebab & Usulan Perbaikan \\
\hline Metode & $\begin{array}{l}\text { Program kerja yang berupa } \\
\text { preventive maintenance behm } \\
\text { berjalan dengan baik }\end{array}$ & $\begin{array}{l}\text { Menerapkan program kerja preventive } \\
\text { maintenance menjadi program kerja utama } \\
\text { bagian maintenance untuk dapat merawat } \\
\text { mesin dengan baik dan benar }\end{array}$ \\
\hline Manusia & $\begin{array}{l}\text { Jadwal perawatan rutin behum } \\
\text { tersusun }\end{array}$ & $\begin{array}{l}\text { Membuat jadwal perawatan rutin/berkala } \\
\text { yang meliputi jadwal inspeksi, pehumasan, } \\
\text { cleaning mesin, dsb. }\end{array}$ \\
\hline Mesin & Cooling tower kotor & $\begin{array}{l}\text { Membuat jadwal cleaning mesin cooling } \\
\text { tower secara rutinberkala }\end{array}$ \\
\hline \multirow{2}{*}{ Lingkungan } & $\begin{array}{l}\text { Area mesin kotor karena terdapat } \\
\text { debu powder berterbangan }\end{array}$ & $\begin{array}{l}\text { Menekankan program } 5 \mathrm{~S} \text { kepada setiap } \\
\text { pekerja }\end{array}$ \\
\hline & Air cooling tower kotor & $\begin{array}{l}\text { Membuat jadwal cleaning mesin cooling } \\
\text { tower secara rutinberkala }\end{array}$ \\
\hline
\end{tabular}

yang berupa pressure pressing abnormal pada mesin Pressing PH-1400 Line 104 dapat dilihat pada Tabel 4.15:

(Sumber: Hasil Pengolahan Sendiri) 


\section{Analisa Biaya Perawatan Mesin}

1. Biaya Perawatan Mesin

Diketahui biaya pergantian komponen perawatan mesin Pressing PH-1400 dan Mesin Cooling Tower pada tahun 20122016 adalah sebesar IDR 770,825,303.00,-.

2. Biaya Tenaga Kerja Untuk Perawatan Mesin Biaya perbaikan kasus Breakdown Machine Pressure Pressing Abnormal dari tahun 2012-2016 dihitung dengan rumus:

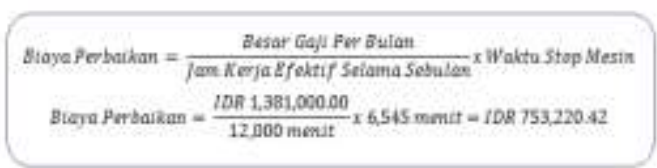

Berdasarkan perhitungan diatas diketahui biaya tenaga kerja untuk perbaikan mesin Pressing PH-1400 Line 104 pada tahun 2012-2016 adalah sebesar IDR 7,497,922.44,-.

3. Biaya Kehilangan Produksi Selama Perawatan

Biaya kehilangan produksi akibat Breakdown Machine Pressure Pressing Abnormal dari tahun 2012-2016 dihitung dengan rumus:

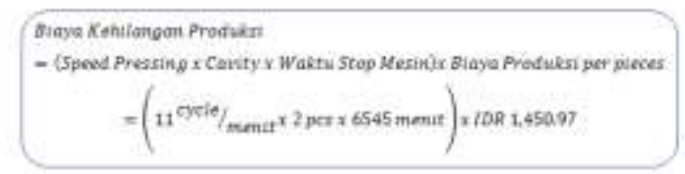

Berdasarkan pada hasil perhitungan diketahui bahwa biaya kehilangan produksi akibat Breakdown Machine Pressure Pressing Abnormal dari tahun 2012-2016 adalah sebesar IDR 1,364,542,983.02,--

\section{M.Analisa Biaya Pembelian Mesin Baru}

1) Biaya Pembelian Mesin Baru

Berdasarkan pada hasil perhitungan diketahui bahwa estimasi biaya pembelian mesin Pressing PH-1500 baru adalah sebesar IDR 5,371,4 42,219.87,-.

2) Biaya Kehilangan Produksi Selama Install Mesin Baru

Berdasarkan pada hasil perhitungan diketahui bahwa biaya kehilangan produksi akibat Pemasangan Mesin Pressing PH1500 Baru adalah sebesar IDR 91,478,700.80,--

3) Biaya Tenaga Kerja Selama Install Mesin Baru
Berdasarkan pada hasil perhitungan diketahui bahwa biaya tenaga kerja pemasangan Mesin Pressing PH-1500 Baru adalah sebesar IDR 13,345,419.41,--

\section{N. Analisa Perbandingan Biaya Perawatan Mesin dan Pembelian Mesin Baru}

Hasil perbandingan biaya perawatan dan biaya pembelian mesin baru dapat dilihat pada Tabel 4.24:

Tabel 4. 4: Perbandingan Biaya Peratratan dengan Biaya Pembelian Mesin Baru

\begin{tabular}{|c|c|c|c|c|c|}
\hline \multirow{2}{*}{ No } & \multirow{2}{*}{ Deshrpsi } & \multicolumn{2}{|c|}{$\begin{array}{c}\text { Baya Rermotan } \\
\text { Mesit Prescing PH-100 }\end{array}$} & \multicolumn{2}{|c|}{$\begin{array}{c}\text { Baya Pabefan } \\
\text { MrinPrewig BaruPH1500 }\end{array}$} \\
\hline & & D2 & $72,325,303.90$ & $\mathbb{1} R$ & $5,371,42219,97$ \\
\hline 2 & Baza Terag Reri & 128 & $7,497,922,4$ & IDR. & $13,45,41941$ \\
\hline 3 & Brya Keliengen Protis & DR & {$[364,54,983,02$} & $\mathbb{1 D R}$ & $91,48,7030$ \\
\hline & Total & $\mathrm{DR}$ & $2,142,866,208.45$ & $\mathbb{D R}$. & $5,476,266,340008$ \\
\hline
\end{tabular}

Berdasarkan pada hasil perbandingan maka diperoleh biaya perawatan merupakan biaya terendah dengan nilai IDR $\mathbf{2 , 1 4 2 , 8 6 6 , 2 0 8 . 4 6 , -}$ dan biaya pembelian mesin baru merupakan biaya tertinggi dengan nilai IDR $5,476,266,340.08$,-.

\section{KESIMPULAN DAN SARAN}

\section{A. Kesimpulan}

Berdasarkan hasil analisis dan perhitungan nilai OEE pada mesin Pressing PH-1400 Line 104 dapat diambil kesimpulan sebagai berikut:

1. Nilai efektifitas pada mesin Pressing PH1400 Line 104 diperoleh dari hasil perhitungan dengan metode OEE yaitu berkisar antara $71.55 \%-92.00 \%$ dengan nilai rata-rata sebesar $83.56 \%$ menunjukkan nilai dibawah standar. Nilai availability rate berkisar antara $84.32 \%$ $93.00 \%$ dengan rata-rata $89.28 \%$. Nilai performance rate berkisar antara $77.18 \%$ $99.73 \%$ dengan rata-rata $94.01 \%$. Nilai quality rate berkisar antara $99.53 \%$ $99.73 \%$ dengan rata-rata $99.65 \%$. Faktor yang mempengaruhi nilai efektifitas mesin Pressing PH-1400 Line 104 adalah breakdown machine dengan kasus tertinggi 
2. yaitu pressure pressing abnormal (tidak stabil).

3. Perbandingan finansial antara biaya perawatan dan biaya pembelian mesin baru menunjukkan bahwa biaya perawatan

\section{DAFTAR PUSTAKA}

Ansori, Nachnul Dkk. 2013. Sistem Perawatan Terpadu. Penerbit: Graha Ilmu, Yogyakarta.

Delbecq A. L. \& VandeVen A. H. 1971. A Group Process Model for Problem Identification and Program Planning, Journal Of Applied Behavioral Science VII

Gubata, Joyce. 2014. Just-in-time Manufacturing. Researchstarters Business.

Herjanto, E. 2007. Manajemen Operasi. Jakarta: Grasindo.

Kurniawan, Fajar. 2013. Manajemen Perawatan Industri. Penerbit: Graha Ilmu, Yogyakarta.

Liker, Jeffrey K. 2008. Toyota Culture. Penerbit: Erlangga, Jakarta.

Moleong, Lexy J. 2007. Metodologi Penelitian Kualitatif. Penerbit PT Remaja Rosdakarya Offset, Bandung.

Pranoto, Hadi MT. 2015. Reability Centred Maintenance. Penerbit: Mitra Wacana Media, Jakarta.

Pitono, Wuguh. 2015. Tugas Akhir Analisis Efektifitas Mesin Extruder Denga mesin memiliki biaya lebih rendah yaitu sebesar IDR 2,142,866,208.46,dibandingkan dengan biaya pembelian mesin baru yaitu sebesar IDR 5,476,266,340.08,--.

Metode Overall Equipment Effectiveness (OEE) Untuk Perbaikan Proses di PT. Sinta Prima Feedmill. Universitas Pamulang, Tangerang Selatan.

Purba, H.H. 2008. Diagram fishbone dari Ishikawa. [internet]. Tersedia dalam: http://hardipurba.com/index.php/2008/09/ 25/diagram-fishbone-dari-ishikawa/ [diakses pada tanggal 6 Desember 2016].

Shirose, Kunio. 1996. Program Implementasi Baru dalam Industri Pabrikasi dan Rakitan. Japan Institute of Plant Maintenance. Tokyo-Japan.

Supriyono, R.A, 2000. Sistem Pengendalian Manajemen, Edisi Pertama, Buku Pertama. BPFE, Yogyakarta.

Tague, Nancy R. 2004. The Quality Toolbox, Second Edition. ASQ Quality Press.

Tague, N. R. 2005. The Quality Toolbox. Winconsin. ASQ Quality Press.

http://disnakertrans.bantenprov.go.id diakses pada tanggal 15 Mei 2016 Pkl. 09.00 WIB.

www.oee.com diakses pada tanggal 06 Desember 2016 Pkl. 09.25 WIB.

www.sacmi.com diaks s pada tanggal 19 Mei 2016 Pkl. 10.00 WIB. 